Cost Mrese Act.-'The Secretary for Mines has made an Order relating to the testing of mine-dust mixtures containing gypsum and prescribing that such mixtures shall be dried at a temperature not exceeding $275^{\circ} \mathrm{F}$., instend of $212^{\circ} \mathrm{F}$., in order to ascertain their moisture content. In other respuets the procedure is the same as in the standard test laid down in General Regulation 4 of July 30, 1920, made under the Coal Jines Act, 1911.

Centificatis ix Chrmistix.--I'he Secretary of the Board of Education announces that an agreement has been made under which the Jnstitute of Chemistry and the Board will issue jointly certificates in pure and applied chemistry to students in technical schools in lingland and Wiles who have successfully completed approved courses. The Institute will consider later whether and how far the higher certificates can be regnrded as a qualification for admission to the examination for the Associateship Details of the scheme havo been issued by the lloard in pamphlet form. [Rules $100.1921 .2 \mathrm{2l}$.]

Sarfauandivg of Innustuins Act.-The Bonrd of T'rade has received complaints under Section $1(5)$ of the Act that incandescent gas mantles and calcium carbide havo been improperly excluded from the lists of articles published by the 13oard. "The Incandescent Mantle Oranufacturers' Association is the complainant it tho first case and the Jritish Cellulose and Chemical Manufacturing Co. in the second. The hearings are fixed for December 3 and 10, respectively, and persons directly interested in cither dispute are osked to comununicate immediatrly with the complninants, or with the Bond.

\section{TRADE NOTES.}

\section{BRITISII.}

The Dye Market in Indin.--Jmports of dyeing and tanning materials into lndin in 1920-21 rose in value by 1Rs.1.5 crore to RN.302 rrore, of which Germany supplied 35, the United Kingrom 27 , and tho U.S.A. 21 per cent. Tluo principal items were aniline worth lls.2.23 crore (U.K. $31 \%$, Germany $29 \%$ ) and alizarin valued at 12 s.55 lakhs (U.K. $17 \%$ Germany $67 \%$ ). 'Irado with Germany has increased owing to the removal of restrictions on the importation of synthetic dyestuffs. Ainong imports from Great Britain wero largo quantities of reparation dyes. The distribution of dyestuffs in India is controlled in order that consumers may not be charged exorbitant prices.-('limes Tr. Silup., Nov. 12 1921.)

Northern Territories of the (hold Coast in 1919.-The chicf crops grown in this Colony are beans, groundnuts, maize, various cereals, cotton, tohacco, and sisal, and the aren under cultivation is steadily increasing. Gold-benring quart: and alluvial deposits occur near $W$ and in tho Bole district but aro not worked owing to lack of transport facilities. Finvourable reports on specimens of mica from the north-west province have been recoived, but tho outcrops haro not yet been investignted. Jron ore is smelted by the natives in various localities, and salt is produced ly evnporntion at Baboya. No details are given of the trade of the Protectorate lut it is stated that there was an increaso in tho exports of shea lutter, exhracted from the fruit of Butyrospermum Parlii, and of "dawa dawa, "a food mado from the locust bean (l'arlia flicoidea).-(Col. Rep.-Ann., No. 1082, 1021.)

Nyasaland in 1919-20.-Tho agricultural dovelopment of Nyasaland is now passing through a very critical period; tho value of land has increased by about 140 per cent. sinco 1014, and many sottlers havo sold their estates and left the country. The cotton crop declined by 79 tons to $262 \mathrm{t}$., but the production of fibre shows signs of increasing. 'lhero was a reduced demand for capsicums and chillies, which were used in the manufacturo of "tear" shells during the war. 'The investigation of the coal and other mineral deposits was continued by the Government Geologist. Imports were valued at $£ 606,624$, of which the United Kingdom supplied 61 and British Possessions 17 per cent.; 99 per cent. of the exports, valued at $\mathbb{E}_{130,223}$, was clirected to the United Fingdom. The prospects of the Protectorate are held to be promising; transport is improving and increasing numbers of settlers aro arriving. 'l'he cultivation of cotton and sisal hemp should develop into important industries.-(Col. Rep.-ilnu., No. 1075, 1921.)

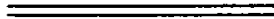

\section{REVIEWS.}

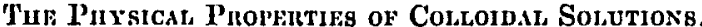
By E. F. Buntos. Second calition. $\Gamma^{\prime} p$. viiit 221. (London: Longmans, Green and Co. 1921.) Price 12s. 6d. net.

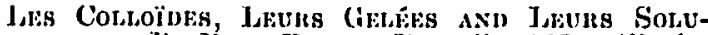
Tioss. By Paur Banr. P'p. xii.+508. (L'aris: 7)unod. 1921.) Price 50 francs.

Jurton's work, the first edition of which appeared in 1914, deals almost exclusively with tho suspensoid sols. 'This limitation is very natural in a book written for physicists by ono of them, but it may cause disappointment to many readers, and the familiar statements regarding tho technical importance of the discipline are a little difficult to support on this bisis. 'The portion of the subject chosen by the author is trented very lucidly and in grent-sometimes perhaps excessive-detail : the general render will hardly refuire a verbitim quotation of layleigh's exposition of microscopic inutge formation. A long and admirable chapter is devoted to the Brownian morement, and tho author gives an original deduction to show why tho law of logarithmic distribution cannot apply to columns of any considerable height, a point ignored in most text-books. As might be expected, the chapters on the electrical properties and congulation are also excellent, and recent literature has been fully utilised in eriticising the "valency rules." Tho author, in this comnexion, makes some very striking suggestions regarding tho grent differenco between uni- and tervalent ions, which it is hoped he will test experimentally.

A few statements aro open to controversy, as is, indeed, inevitable in the present state of the subject. One of these perhaps deserves mention: tho anthor distinguishes botween sols in which the disperse phase is a pure substance, and those in which electrolytes are necessury' for stability. 'I'he most general view is certainly that the former class is non-existent, and that in all cases definito ions are reguired in a stable nol. 'Ihis, and a fow similar points, in no way detrict from the value of tho book, which can bo thoroughly recommended to all students who look for more than mere "Lips" of immediato technienl utility.

Bury's book is in many respects a very romarkablo work. In moro bulk it exceeds every existint text-book dovoted to the subject. It contains an chormous mass of material, the selection of which not only proves a comprehensive knowledge of the literature, but is strikingly originnl in many cases, and its presentation conforms to tho high national standard of lucidity and of formal logical dovelopment. T'ho reviewer finds himsolf in dively 
sympathy with several features, such as the elaborate treatment of gels, the phenomona of swelling and the properties of nou-aqueous systems (the author exhibits a marked partiality to india-rubber). It is more difficult to be with him when he deliberately abandons tho modern views regarding the generality of the colloidal state and goes back-at any rate in the chronological sense- to purely chemical theories. A largo section of the book is devoted to "Isa Colloidite" and to developing the thesis that sol-formation is bound up with polymerisation. In cases in which the author himself excludes this possibility, c.g., with salts of univalent metals, he draws distinctions which, to the student of modern Iinglish and German liternture, will seem entirely urlitrary. Non-aqueons sols and gels of $\mathrm{NaCl}$, and liydrosols of $A$ gI and $\mathrm{AgBr}$ are known which, to the majority of observers, will apponr as completely typical as the preparations in which polymerisation is yossible. It is impossible within tho limits of it brief review to discuss this fundamental question.

'l'he treatment of the recognised aspects of the subject, such as viscosity, electrical properties, congulation, etc. is very complete, and throughont takes into consideration recent literature. Only one very important addition to our knowledge appears to have been orerlooked: the examinations of colloidal particles loy $\mathbf{X}$-ray interference, by Debye and Scherrer (1917 and since). They bear direetly on the ruestion of the density of ultramicroscopic particles: as gold particles containing only a few hundred atoms have the same spacelattico as solid gold they must have the same donsity, a point on which the anthor is sceptical they also seem to show the very grent rareness of "t truly "smorphons" stato, to which ho attaches importance.

'The mere size of the book will probably deter heginners from its study. It will prove stimulating to readers familiar with tho subject, especially to those who do not dislike having their convictions challenged by the ablo presentation of very unfamilinr viows.

Eu!, Hatschek.

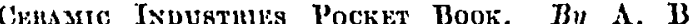
Skante. P'p. viit267. (Isondon: Sir Isaac P'itmen and Sons, Ltd. 1920.) Price 8s. Bd. net.

This pocket-book contains in a handy form, not only a number of data constantly required by thoso ongaged in ceramic industries, but also a Inrgo amount of information which might be wanted at any time, and might necessitate a long search to find. It is one difliculty of tho subject that information on it is widely scattered and not always ensily accessible.

The autlior has wisely extended tho term " coramic" to include severnl industries which at lirst sight would apponr to bo outside its scope, and it is to bo regretted thet he has not discussed rather more fully tho clnssification on pages 1 and $11-12$. It must be borne in mind, that a book of this kind, whilst written primarily for those engaged in coramic industries, will bo welcomed by many not actunlly concerned with the manufacture but with tho selection and purchase of cerumic products, and for them a clenr explanation of many technicnl terms would be of great assistance. Many of these aro givon, but somowlat noticenblo exceptions aro: "on-glazo" und "under-glnzo" colours, "ongobo," ete., and altlough not susceptilile of exnct definition, nn explanation, for example, of "crasing," " dinnted wire," "softening point" and "squating temperaturo" would havo been valuablo.

$\Lambda$ largo portion of the book is givon up to monsuration, mechunics, and ongincering data. Al- though this information is undoubtedly useful, tho question not unnaturally arises as to tho advisability of including it in a book of this kind, becauso it would ordinarily be sought in engineering pocketbooks, and one feels that much of this space could have been more profitably devoted to purely ceramic matters. If a certain amount of mathematicos is included short tibbles of lognrithms and trigonometrical formula might certainly have been inserted. The arrangement of the subject matter in a book of this lind must always be a difficult problem, but the inclusion of the physical constants of porcelain among notes on clay's is rather a surpriso. The inclusion of moro physical data of ceramic products, stuch ats expansion and conductivity, in particular, would have been of great service, or even tho tablo compiled by Wologdino with epecinl reference to refractory materials. A description of the physical testing and chemicnl analysis of cornmic matorials and products vould also havo been much appreciated by readers who aro concerned with tho selection and uso of such products, and aro conseguently interested in tho interprotation of tho results of tests, and are often at a loss to appreciato their significance.

Tho typographical errors are comparatively few and unimportant. On page 15, line 25, "air compounds" should apparently be "iron compounds," and the specilic kravity of crystobalito on page 25 , should bo 2.33 instend of $2 \cdot 65$.

Tho concluding section of tho book, on ceramic calculations, is very clearly set ont, and will be of great use to students as well as those engaged in pottery unanufacture, and the full working out of actual examples will enable tho uninitiated to mister the subject.

Though differences of opinion may exist as to the selection and arrangement of tho subject-matier of the book, there is no doubt that this compact little rolume will be valued by those engaged in tho various branches of the ceramic industries, who will realiso that it fills : galp which no other book of its size has hitherto done.

Wasteh C. Hascock.

\section{$=$ \\ OBITUARY.}

\section{F. W. PASSMORE.}

Francis William Passmore, who died suddenly on October 29, was born in Iondon in 1868, his father boing the sub-cditor of tho l'harmaceutical Journal. His chemical training began in the laboratory of tho late Dr. B. H. Paul, to whom he was articled for five years, and was continued at the school of the Pharmacentical Society and at tho University of Wiirzburg undor Bnil Fischer, who subsequently wrote of him:- "I regurd him as one of the most talented of my pupils; he possesses an extrnordinary gift for observition and chemical research." After two years' study' in 'Viiraburg ho obtained tho dogreo of Pli. D., summa cum laule.

Returning to liugland, lo sorved as assistant demonstrator in the research laboratory of the Phurmacentical Society, under Prof. W. R. Dunstan, and in 1892 ho started practice, with MIr. H. Helbing, as a consulting chemist in London, tha partnorship boing subsergontly dissolved. In this sphero do was very successful and became widely known as an autliority in logal matters relating to chemicul patonts. Among tho cases in which his nssistance was requisitioned wero actions connected with Janolin, rhodumino dyes, ionone, synthotio musk, sulphur dyes, nspirin, metul-filament lanps, sacchnrin, blonching of flour, urtificial silk, and fat-hardoning. 